\title{
Duch Hamleta na szklanym ekranie
}

\section{Depictions of Hamlet's Father's Ghost on Silver Screen}

\author{
|Agnieszka Kwiatkowska
Uniwersytet im. Adama Mickiewicza w Poznaniu
}

\begin{abstract}
Every adaptation for the screen, film adaptation or a play put on stage includes the elements of interpretation of a literary work and determines the particular way it is interpreted. To illustrate this notion, the article introduces film adaptations of Shakespeare's Hamlet. Big-screen versions of Hamlet directed by Laurence Olivier, Alan Dent, Akira Kurosawa, John Gielgud, Bill Colleran, Grigori Kozincew and Franco Zeffirelli are referred to in the text. Particular attention is given to the character analysis of Hamlet's father's ghost, variously depicted in the following film adaptations of the Shakespearean drama.
\end{abstract}

Key words: Hamlet, Shakespeare, film adaptation, adaptation, Hamlet's father's ghost.

Streszczenie: Każda ekranizacja, adaptacja filmowa lub wystawienie na scenie zawiera w sobie elementy interpretacji dzieła literackiego i determinuje określony sposób jego odczytania. Artykuł prezentuje to na przykładzie ekranizacji i adaptacji Hamleta Szekspira. W tekście przywołano dzieła filmowe takich twórców jak Laurence Olivier, Alan Dent, Akira Kurosawa, John Gielgud, Bill Colleran, Grigori Kozincew i Franco Zeffirelli. Ze szczególną uwagą omówiona została postać ojca Hamleta, różnorodnie przedstawiania w kolejnych ekranizacjach szekspirowskiego dramatu.

Słowa kluczowe: Hamlet, Szekspir, ekranizacja, adaptacja, duch ojca Hamleta.

Adaptacje i ekranizacje literatury pięknej często wśród szkolnych dydaktyków budzą ambiwalentne emocje. Przeniesione na ekran bądź wystawione na teatralnych deskach arcydzieła niejednokrotnie ulegają licznym uproszczeniom, a wyznaczone przez reżysera kierunki interpretacji mogą zdominować odbiór tekstu, odebrać mu wieloznaczność, głębię i uniwersalnych charakter. Filmy zrealizowane na podstawie kanonicznych tekstów kultury bywają też bardzo niesłusznie traktowane jako nowoczesny odpowiednik prymitywnych bryków i streszczeń, a przedstawione $\mathrm{w}$ nich odczytanie dzieła odbierane jest przez uczniów jako jedyna możliwość lektury. Takiemu podejściu skutecznie zapobiega świadoma recepcja, poparta nie tylko 
znajomością tekstu literackiego, ale i fundamentalną wiedzą o zasadach interpretacji. Uświadamianie uczniom, że każda próba przełożenia dzieła literackiego na język filmu lub teatru to jedno z wielu możliwych odczytań, eksponujące wybrane aspekty utworu, pozwala efektywnie wykorzystywać ekranizacje na zajęciach. Nagrania adaptacji teatralnych czy fragmenty filmowe zestawione $\mathrm{z}$ literackim pierwowzorem mogą odsłonić ukryte sensy, zwrócić uwagę młodzieży na istotne zagadnienia lub pomóc w odniesieniu uniwersalnego przesłania do konkretnej - historycznej lub współczesnej rzeczywistości. Zderzenie różnych adaptacji wybranego dzieła literackiego dodatkowo może wydobyć istotę sztuki interpretacji, która pozwala szukać sensów w sposób subiektywny i zindywidualizowany, ale zakorzeniony w tekście i zintegrowany z jego przesłaniem. Takie działanie nabiera szczególnego wymiaru w odniesieniu do ekranizacji dramatów - tekstów przeznaczonych do wystawienia, w których istotne są zarówno wszystkie miejsca, przez które dramaturg sugeruje sposób wystawienia sztuki, jak i niedopowiedzenia, pozostawiające swobodę reżyserowi. Przemyślane odwołania do sztuki filmowej w procesie zaznajamiania uczniów z literaturą są więc nie tylko szansą na wzbogacenie i pogłębienie odczytania lektury, ale stanowią też pretekst do wprowadzenia podstawowych reguł analizy i interpretacji dzieła, uruchomienia pojęć z zakresu przekładu intersemiotycznego czy ukazania wieloznaczności i uniwersalnego charakteru przesłania jako integralnej cechy arcydzieła. Pozwalają też zapoznać uczniów z dokonaniami wybitnych reżyserów oraz przedstawić kino i teatr jako dziedziny sztuki wysokiej, oferującej teksty kultury równorzędne wobec największych arcydzieł literackich.

Reżyserskie odczytania dzieł wieloznacznych, trudnych w odbiorze, piętrzących pytania i wątpliwości niejednokrotnie skłaniają młodzież do dyskusji i przemyśleń, a ostatecznie pomagają wybrać własną ścieżkę interpretacyjną, przygotowując do formułowania argumentów wspierających wybrane tezy. Przykładem celowego wykorzystania filmów w procesie dydaktycznym może być cykl lekcji dotyczących twórczości Szekspira, szczególnie bardziej wnikliwa interpretacja wybranych scen Hamleta, analizowanych nie tylko na podstawie tekstu w wybranych przekładach (Paszkowskiego, Słomczyńskiego i Barańczaka), ale także zwracając uwagę na celowo dobrane fragmenty ekranizacji. Zderzenie różnych tłumaczeń poszczególnych scen - językowych i intersemiotycznych - przydatne wydaje się między innymi dla zrozumienia wahania Hamleta, a zwłaszcza dla zanalizowania postawy duńskiego królewicza wobec zjawy zmarłego ojca.

Historia scenicznych i filmowych adaptacji dzieł Szekspira jest niezwykle bogata. Każde przedstawienie, każda kolejna ekranizacja to oryginalne ujęcia interpretacyjne, podkreślające różne sensy i zwracające uwagę na inne aspekty dramatu. Wielowątkowe i obszerne działa angielskiego dramaturga zmuszają reżyserów do podejmowania odważnych decyzji, konieczności dokonania skrótów skłania do odrzucenia niektórych wątków, 
a tajemniczość świata przedstawionego, w którym realizm i metafizyka przenikają się wzajemnie, wymaga rozważnego zarysowania granicy między scenami o charakterze mimetycznym a wizjami wysnutymi z wyobraźni poszczególnych postaci.

Już w XVIII wieku, kiedy przeróbki sztuk Szekspira zaczęły podbijać europejskie sceny, ukształtowały się dwa nurty ich adaptacji - francuski i niemiecki. Pierwszy - popularyzowany przede wszystkim przez Jeana François Ducisa - zalecał całkowite podporządkowanie dzieł Szekspira normom i regułom klasycyzmu. Drugi w znacznie mniejszym stopniu przekształcał szekspirowskie założenia. Kultura niemiecka wkraczała już wówczas w okres burzy i naporu, dzięki poświęconym Szekspirowi publikacjom Lessinga i Herdera oryginalny angielski wzorzec uległ niewielkim deformacjom, a kolejne adaptacje sceniczne - choć nie wolne od przeróbek i pozbawione szczególnie złowrogich scen - zdołały zachować szekspirowską wizję świata. Dla polskiej recepcji Szekspira ogromne znaczenie ma fakt, że Wojciech Bogusławski przygotował wystawienie Hamleta, opierając się na niemieckiej wersji F. L. Schrödera. Decyzja ta wywarła również wpływ na rozwój rodzimego teatru i dramatu, który stawał się coraz bardziej podatny na nadchodzące idee romantyzmu (Wołoszyńska 1960, 61).

Interpretacja scen o charakterze metafizycznym (przez metafizykę rozumiem tutaj wszelkie dowołania do świata pozazmysłowego oraz sugestie, że rzeczywistość poznawana sensualnie jest swego rodzaju zasłoną, za którą rozpościera się przestrzeń doświadczeń emocjonalnych i duchowych), odczytanie ich jako integralnej wizji świata lub projekcji wyobraźni czy podświadomości postaci, pozwala sytuować dzieła Szekspira zarówno jako kolejny etap ewolucji klasycznie pojętego dramatu, jak i początek procesu, który doprowadził do romantycznej rewolucji w obrębie konwencji rodzajowej. Wieloznaczność tego rodzaju można zaobserwować m. in. w Hamlecie, w jednej z początkowych scen dramatu, kiedy młody książę rozmawia z duchem swego ojca - podstępnie zamordowanego króla Danii. Postać Ducha starego króla - sposób jej wprowadzenia do utworu, interakcje z innymi bohaterami, odczytanie intencji, wreszcie klasyfikacja etyczna dążenia do zemsty - jest kluczowa dla całej intrygi dramatu. Słowa zmarłego ojca pchają Hamleta do działania, a niepewność towarzysząca całej wizji staje się głównym źródłem wahań i rozterek nieszczęsnego księcia. Zjawę, przechadzającą się po murach obronnych, najpierw w przywołanej retrospekcji obserwowali strażnicy - Bernardo i Marceli, którzy poinformowali o tym Horacego. Ten początkowo nie wierzył w ducha, ale kiedy kolejnej nocy sam go spotkał, przestał podważać jego istnienie. Co więcej, rozpoznał w zjawie zmarłego króla i zyskał pewność, że to właśnie on powrócił z zaświatów. Swymi spostrzeżeniami podzielił się z Hamletem, nie mówiąc już - jak wcześniej strażnicy - o podobieństwie, lecz raczej o tożsamości widma i króla. Młody książę zadając kolejne pytania i weryfikując odczucia przyjaciela, stara się potwierdzić tożsamość Ducha. Zestawienie 
pierwszej i drugiej sceny pierwszego aktu oryginalnej wersji dramatu - na co zwracają uwagę Gibińska i Tabakowska - uwypukla zarówno powtórzenia w opisie wyglądu widma, jak i różnice w sposobie jego rozpoznania najpierw sygnalizowanego tylko jako podobieństwo, później prowadzącego do utożsamienia ze starym królem (Gibińska, Tabakowska 1993, 58). Badaczki podkreślają też rolę środków językowych, zwłaszcza sposobu wprowadzenia zaimków, które służą zasygnalizowaniu i podkreśleniu ewolucyjnego charakteru postrzegania kontrowersyjnej postaci:

w scenie pierwszej słowa wchodzą w bezpośrednią relację z obrazem i interpretują to, co widać, podczas gdy w scenie drugiej przypominają wyinterpretowany wcześniej obraz, potwierdzając zarówno prawdę doświadczenia, jak i prawdę interpretacji. Ta zmiana jest sygnalizowana przez konsekwentne stosowanie (...) terminów, w jakich określana jest zjawa. (...) W pierwszej scenie o duchu mówi się this thing, this dreaded sight, this apparition, a więc w sposób naturalny również it. Zaimek osobowy he jest zarezerwowany wyłącznie dla nieżyjącego króla. Użycie zaimków w scenie 2 jest decydujące dla interpretacji stosunku Horacego i Hamleta do ducha (Gibińska, Tabakowska 1993, 59).

Kolejne formy gramatyczne wyraźnie sygnalizują, że Horacy i Hamlet po wstępnych wahaniach - nie mają wątpliwości, że oto stanął przed nimi duch zmarłego króla. W większości przekładów Hamleta na język polski różnica między stwierdzeniem podobieństwa i tożsamości zaciera się, a pytania o stosunek duńskiego królewicza do widma i jego wypowiedzi są bardzo niepokojące i nie zawsze znajdują rozstrzygnięcie w obrębie samego dramatu. Grę rodzajów gramatycznych po części wykorzystał Józef Paszkowski, określając Ducha w neutrum jako „widmo” bądź „widziadło”. W przekładzie Macieja Słomczyńskiego Hamlet najpierw określa Ducha mianem „zjawy”, aby w dalszych partiach wypowiedzi - gdy rozpozna już tożsamość zmarłego - użyć zaimka osobowego w rodzaju męskim („rysów jego nie mogliście dostrzec?" - pyta swych towarzyszy). Barańczak całkowicie zrezygnował z tego rozróżnienia, koncentrując się na rozpoznaniu zbroi, mimiki twarzy i przełożeniu idiomów określających podobieństwo widma i króla. Lakoniczny zwrot „these hands are not more like” (w. 211212) został $\mathrm{w}$ jego tłumaczeniu rozwinięty tak, aby podkreślał podobieństwo graniczące z tożsamością: „Duch mniej się odeń różnił niż ta dłoń / Od drugiej dłoni”. Czy jednak Hamlet - bohater przekładów Paszkowskiego, Słomczyńskiego lub Barańczaka - rzeczywiście jest przekonany, że rozmawia ze zmarłym ojcem? Czy wierzy w opowieść o królobójstwie, którą od niego usłyszał? I wreszcie, jeśli rzeczywiście rozpoznał w widmie starego króla, dlaczego waha się, czy wypełnić jego zalecenia i pomścić zdradziecko otrutego? Nie sposób jednoznacznie rozstrzygnąć, z jakiej sfery zaświatów przybywa Duch. Jest posłańcem Niebios czy Piekieł? Czy pragnienie zemsty, które podsyca w swym synu, to szlachetne dążenie do dziejowej sprawiedliwości czy może zgubna namiętność, która jak zazdrość w Otellu czy żądza władzy w Makbecie gubi jednostki i narody? Otruty podczas snu 
król zapewne nie dostąpił łaski świadomego odejścia z tego świata, nie mógł dobrze wykorzystać godziny śmierci ani wdrożyć rytuałów dobrego umierania. Średniowieczna ars bene moriendi stawia taki zgon w złym świetle, nie dając moribundowi większych nadziei na zbawienie. Nawet jeśli więc Hamlet rzeczywiście jest pewien, że rozmawia ze swym zmarłym ojcem, nie może zyskać pewności co do jego kondycji i intencji jego wypowiedzi.

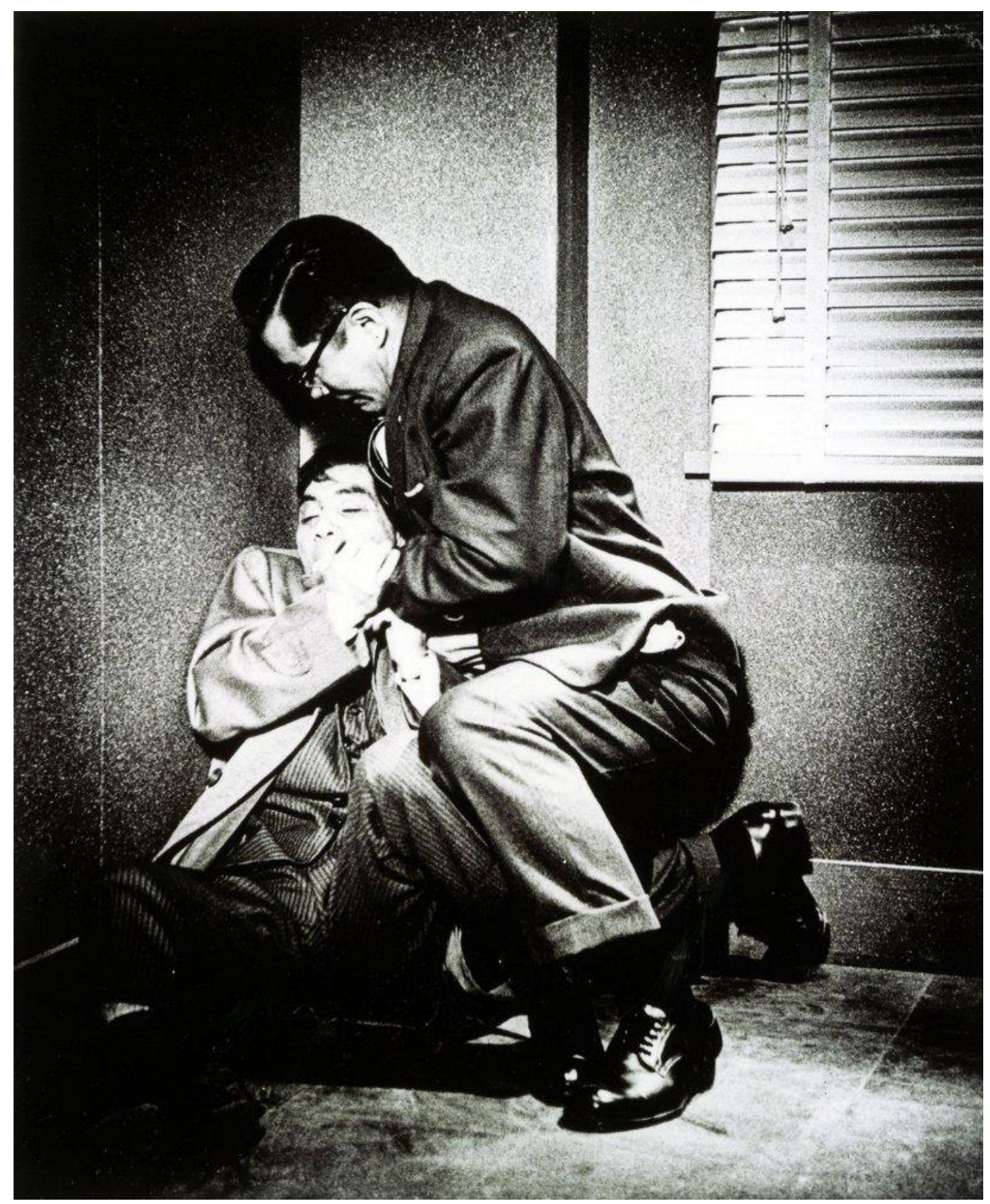

Toshirô Mifune i Kô Nishimura w filmie Zły śpi spokojnie (1960)

Polonistyka. Innowacje 
Kolejne wystawienia i ekranizacje dramatu Szekspira przynoszą rozmaite, niekiedy skrajnie różne kreacje Ducha, które dodatkowo oświetlają interpretacje tej postaci. Hamlet wielokrotnie wystawiany na scenie i ekranizowany stał się podstawą wielu adaptacji, niejednokrotnie bardzo od siebie odległych i niezwykle oryginalnych, przystosowanych do różnych kręgów kulturowych. Do dwóch najstarszych modeli wystawiania Szekspira francuskiego i niemieckiego - dołączyły $\mathrm{m}$. in. charakterystyczne aranżacje rosyjskie i japońskie, jak na przykład spektakl Hamlet Yamoto No Nishikie utrzymany w stylu teatru Kabuki czy słynny film Zły śpi spokojnie (1960) Akira Kurosawy, w którym nieszczęsna Yoshiko kocha ksiecia Nishi (Burnett 2013, 77). Z kolei Grigori Kozincew - reżyser radzieckiej ekranizacji Hamleta z 1964 roku - ukazał dwoistość ducha, możliwość różnorodnego interpretowania tej postaci, nawiązując w jej kreacji równocześnie do tradycji heroicznej i komicznej - do japońskiego teatru No i do amerykańskiego serialu o Batmanie (Burnett 2013, 110).

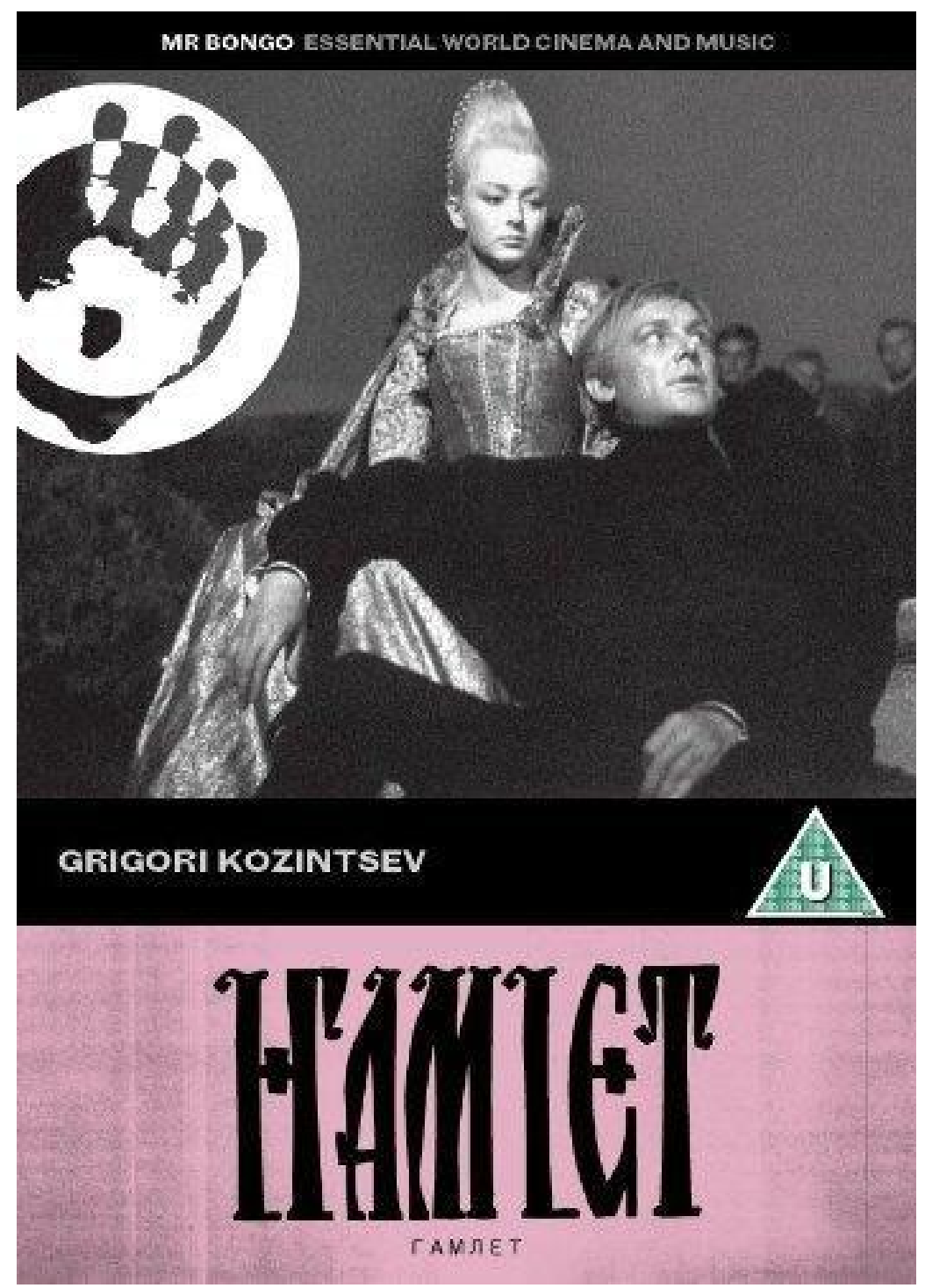

Plakat Hamleta w reż. G. Kozincewa (1964), Innokentiy Smoktunovskiy i Anastasiya Vertinskaya

Polonistyka. Innowacje

Numer 4, 2016 
Szczególnie ciekawe dla interpretacji postaci Ducha jest jednak zestawienie trzech realizacji dramatu: sfilmowanego spektaklu z 1964 roku w reżyserii Johna Gielguda i Billa Collerana (z R. Burtonem w roli Hamleta), adaptacji z 1948 roku autorstwa Laurence'a Oliviera i Alana Denta (w duńskiego księcia wcielił się sam Laurence Olivier) i ekranizacji Franco Zeffirellego z 1990 roku (z Melem Gibsonem w roli głównej i Paulem Scofieldem odtwarzającym Ducha).

W sfilmowanym spektaklu Johna Gielguda i Billego Collerana ascetyczne, powściągliwe dekoracje i minimalistyczne kostiumy doskonale korespondują z powszechnym wyobrażeniem Hamleta przyodzianego w czarny strój, często przedstawianego $\mathrm{z}$ medalionem zawieszonym na szyi bądź trzymającego w dłoni czaszkę. Mimetyzm dotyczący świata zewnętrznego został tu zaledwie zasygnalizowany, jak gdyby reżyserzy chcieli skierować uwagę widzów na przeżycia i emocje postaci, analizując zawiłości i skomplikowanie ludzkiej duszy. W przypadku bohaterów dramatu, podobnie jak i w odniesieniu do kreacji otaczającej ich rzeczywistości, powierzchowny chłód oraz pewna oszczędność środków wyrazu skrywają wielkie i niewypowiedziane namiętności. Duch starego króla jawi się tu jako postać mocno odrealniona - jest cieniem, zaledwie zarysem sylwetki. Głos, który dobiega Hamleta, płynie spoza sceny, z bliżej nieokreślonego kierunku. Królewicz czasem zerka w stronę cienia padającego na ścianę, w innych chwilach spogląda poza kard. Być może - jak sugeruje reżyserski zabieg - widzi tam swojego ojca w bardziej konkretnej i realnej postaci, podczas gdy widz może obserwować tylko grę świateł i cieni układających się w różne kształty. Zbroja, która stanowi wyróżnik króla i w dramacie Szekspira jest podstawową przesłanką do rozpoznania, tutaj staje się zaledwie cieniem hełmu. Utożsamienie starego Hamleta ze zjawą pozostaje więc mocno niepewne. Widz musi się opierać na zapewnieniach Horacego i pozostałych bohaterów dramatu. W gruncie rzeczy jednak w samym dramacie Szekspira odbiorca również nie ma kompetencji, aby porównać Ducha i zmarłego króla oraz samodzielnie, na podstawie zauważonego podobieństwa, wysnuć wnioski dotyczące wiarygodności całej wizji. Akcja dramatu rozpoczyna się przecież już po śmierci starego Hamleta, który - jako żywy - nie pojawia się $\mathrm{w}$ żadnej scenie. Liczne konstatacje zarysowane w dialogu między postaciami, uwagi na temat barwy zarostu, rodzaju rynsztunku, jasno zwerbalizowane wrażenie podobieństwa (zdaniem Horacego Duch jest tak podobny do zmarłego, jak dłoń człowieka do drugiej dłoni) nigdy nie będą skonfrontowane z obrazem, który odbiorca mógłby przechowywać w swej pamięci, bo takie wspomnienie po prostu nie istnieje. John Gielgud i Bill Colleran niedopowiedzianą pozostawiają jednak nawet kwestię samego przybycia Ducha, który - być może - jest tylko wytworem wyobraźni młodego królewicza. Pozostali uczestnicy sceny co prawda deklarują, że wcześniej widzieli już zjawę i komentują całe zajście, ale trudno powiedzieć, czy słyszą słowa, jakie Duch kieruje do Hamleta. 
Scena rozgrywa się w mrocznej i złowrogiej atmosferze, którą podkreśla oprawa dźwiękowa i operowanie kolorem. Przedstawienie zostało sfilmowane na czarno-białej taśmie, ale wydaje się, że nawet $\mathrm{w}$ bezpośrednim odbiorze reżyserzy nie epatowali bogatą kolorystyką, z umiarem używając wizualnych środków wyrazu. Odgłosy towarzyszące nadejściu Ducha przypominają natomiast nie tyle salwy i wiwaty zgodnie z tekstem dramatu dochodzące z zamku na Elsynorze, ale raczej grzmoty bądź jęki, w powszechnej świadomości jednoznacznie kojarzące się z metafizyczną otchłanią. Hamlet, który w takich okolicznościach spotyka Ducha, zdecydowanie powinien uważać na to, co wyniknie z tajemniczego spotkania i nie przyjmować bez zastrzeżeń zasłyszanych w rozmowie oskarżeń. Jeśli nawet zjawa, którą widzi, to rzeczywiście cień zmarłego ojca, trudno orzec, czy przybywa z dobrymi intencjami. Pragnienie zemsty może być piekielnej natury, a sam król - niecnie otruty podczas snu - według średniowiecznych przekonań niekoniecznie dostąpił zbawienia.

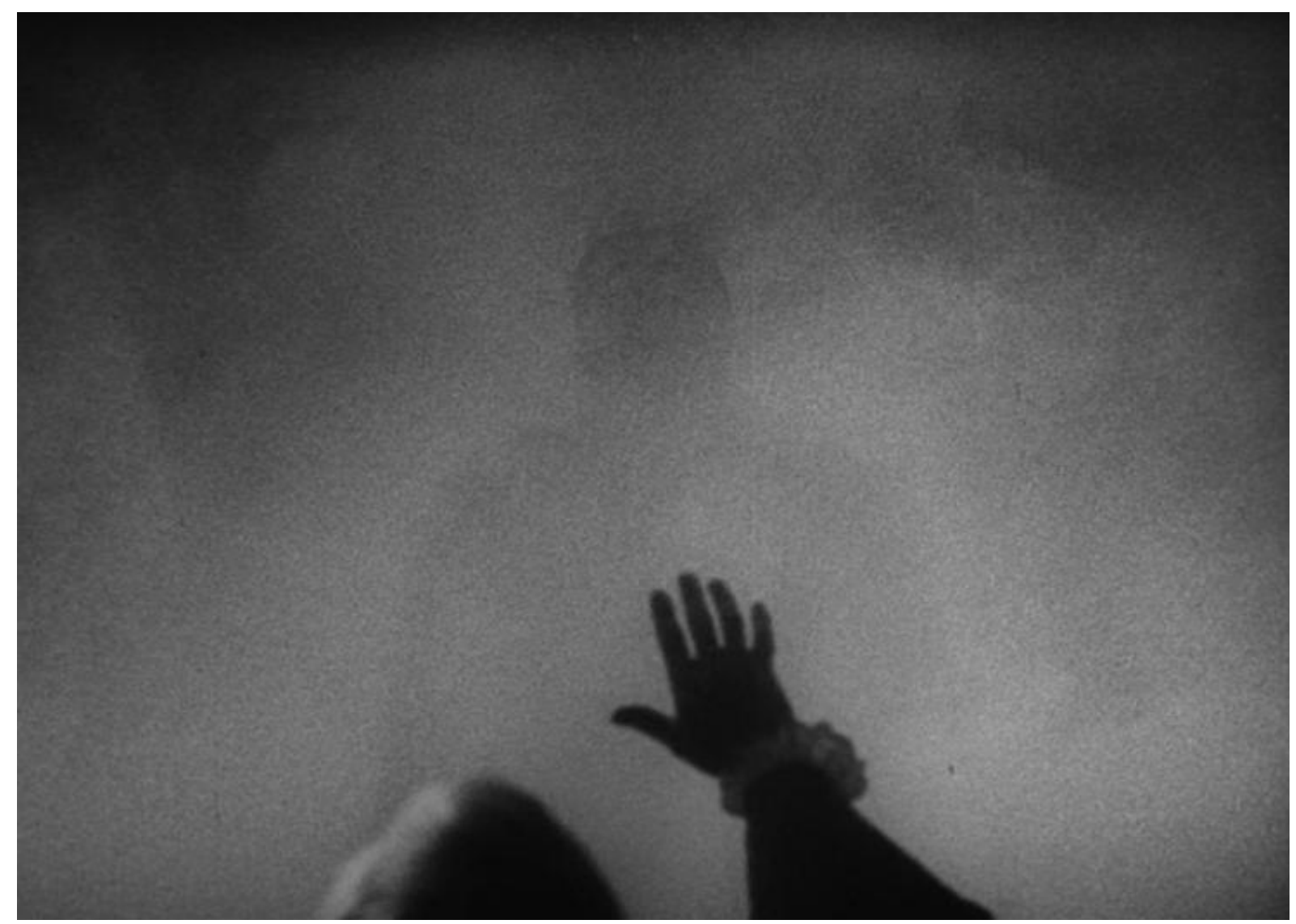

Rozmowa Hamleta z Duchem - kadr z filmu L. Oliviera (1948)

Także Hamlet Oliviera Laurenca rozpoczyna się sceną przywodzącą na myśl gotyckie powieści grozy - ponura twierdza nad brzegiem morza, kondukt żałobny niosący zwłoki królewicza na najwyższą wieżę Elsynoru, aby ostatecznie pogrążyły się one we wzburzonych wodach. Obrazom tym towarzyszą słowa zaczerpnięte sceny IV, aktu I wypowiadane głosem Oliviera Laurenca - reżysera i odtwórcy głównej roli. Status tak skonstruowanego narratora - jak zwraca uwagę Olga Katafiasz - pozostaje jednak 
nieokreślony. Z pewnością nie jest to Horacy, jak można by wnioskować z tekstu tragedii. Może więc duch zmarłego królewicza otwiera tę reżyserską opowieść? Olivier uczynił Hamleta centralną postacią swej ekranizacji, a jego przemyślenia, refleksje, kondycję psychiczną, konstrukcję osobowości, wreszcie położenie i postępowanie uczynił głównym tematem filmu, adaptując go w konwencji dramatu psychologicznego i egzystencjalnego (Katafiasz 2005, 90). Wiele wydarzeń ukazanych zostało jako projekcja wyobraźni tytułowego bohatera, co znacząco podkreśla praca kamery oraz liczne zbliżenia twarzy i głowy księcia. Widać to między innymi w rozmowie ze zmarłym ojcem. Jak pisze Olga Katafiasz:

Wątpliwości okazują się szczególnie zasadne w scenie spotkania z duchem ojca: rozmowę ze starym Hamletem poprzedza odgłos bicia serca następcy tronu i zbliżenie na jego tył głowy, jak gdyby kamera chciała wniknąć w czaszkę postaci. (...) Status ducha również pozostaje niejasny, czemu służą dwa zabiegi. Po pierwsze, mówi on głosem Oliviera; po drugie, sposób wizualizacji opowiadania o morderstwie nie budzi zaufania widza: wygląda ono jak z marionetkowego, rażącego sztucznością przedstawienia - jest raczej wyobrażeniem dziecka niż opowieścią ofiary (Katafiasz 2005, 102).

Olivier nie daje odpowiedzi na pytanie, czy duch naprawdę się pojawia i pożąda zemsty, czy może jest wytworem wyobraźni Hamleta. Być może wrażliwy królewicz jest - jak sugeruje badaczka - „swoistym medium podświadomości otoczenia” (Katafiasz 2005, 103).

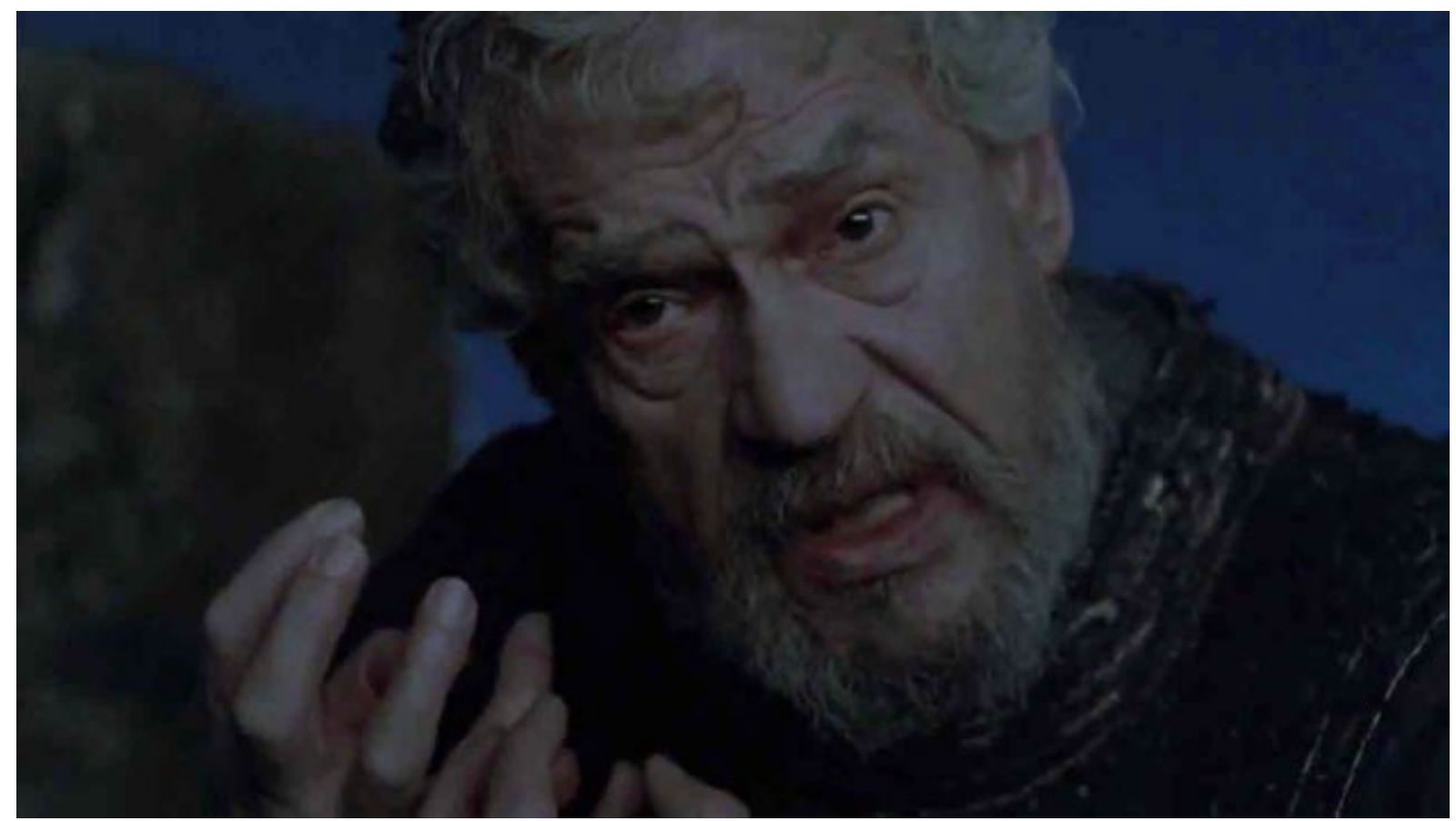

Duch ojca Hamleta - kadr z filmu F. Zeffirellego (1990)

Od omówionych wyżej wyraźnie różni się filmowa kreacja Zeffirellego. W ekranizacji Hamleta z 1990 roku Duch zmarłego króla wygląda bardzo realistycznie. Paul Scofield - który wcielił się w rolę starego Hamleta nie sygnalizuje w żaden bezpośredni sposób swej metafizycznej kondycji, 
bezcielesności czy przynależności do innego, pozazmysłowego świata. Powracając z zaświatów, przybrał postać człowieka i na pierwszy rzut oka niczym nie różni się od pozostałych bohaterów dramatu. Kiedy Hamlet i Horacy wymieniają uwagi na temat podobieństwa widma do króla, opisują zbroję zmarłego czy wspominają kolor jego włosów, odnoszą się nie tylko do swojej pamięci, ale też do realiów, które może zaobserwować widz przyglądający się pośmiertnemu spotkaniu ojca i syna. Jedynie ewidentny brak możliwości nawiązania kontaktu fizycznego oraz złowieszczy szept, którym momentami przemawia widmo, są sygnałami nadnaturalnego charakteru tej sceny. Wyciągnięte dłonie króla nie sięgają młodego Hamleta, ojciec nie może go dotknąć, pociągnąć ku sobie, zawłaszczyć. Jego finalny gest nie budzi pozytywnych skojarzeń, nie jest wyrazem miłości ani pragnieniem przytulenia syna po raz ostatni. Wyraża raczej chęć panowania nad księciem, dążenie do owładnięcia jego myślami i zaszczepienia $\mathrm{w}$ nim pragnienia zemsty. Towarzyszące temu zbliżenie oczu Hamleta pozwoliło badaczom wysunąć przypuszczenie, że Duch - choć tak realistyczny - jest wytworem wyobraźni niestabilnego emocjonalnie księcia (Burnett 2015, 169). W świetle całej sceny taka interpretacja wydaje się jednak mało prawdopodobna, a w kolejnych ujęciach brak przesłanek dotyczących subiektywnego charakteru wizji.

Zestawienie przywołanych ekranizacji, a szczególnie porównanie pełnych metafizycznej grozy i utrzymanych w konwencji metafizycznej wystawień Oliviera oraz Gielguda i Collerana z operującą mimetycznymi środkami wyrazu adaptacją Zeffirellego, pozwala pokazać głębię tej, kluczowej dla interpretacji Hamleta, sceny. Porównanie pozwala nie tylko przyjrzeć się postaci Ducha i przyczynia się do doskonalenia umiejętności interpretacji fragmentu tekstu dramatycznego. Prowokuje też refleksję dotyczącą modelu metafizyki w dramatach Szekspirowskich. Przychodząca z zaświatów zjawa przełamuje bowiem zasadę decorum, a sposób jej przedstawienia odzwierciedla możliwość komunikacji między żywymi a zmarłymi, między materialną rzeczywistością a nieodgadnionym bytem rozpościerającym się poza nią. Czy to, co irracjonalne, pozostaje wytworem ludzkiej psychiki, a wszelkie wizje wyrastają z podświadomości bohaterów? Czy doświadczenie metafizyki jest powszechnie dostępne? Czy świat pozazmysłowy istnieje obiektywnie i - paradoksalnie - może być przedmiotem obserwacji bądź objawiać się żywym w jak najbardziej materialny sposób? Czy emocjonalne piekło, jakiego doświadczają bohaterowie Szekspira i jakie łatwo staje się udziałem ludzi wszystkich kultur i epok, zlokalizowane jest w ludzkiej duszy czy ma swoje zewnętrzne przyczyny? Literatura i kultura nie przynosi odpowiedzi na te pytania, choć rozważanie egzystencjalnych kwestii jest jej fundamentem i w dużej mierze determinuje działalność artystyczną człowieka. Zderzenie różnych - także filmowych - interpretacji wybranego wybitnego dzieła pozwoli jednak pokazać, że na odwieczne pytania ludzkość nie znajduje zadowalającej odpowiedzi, choć kolejne próby jej 
sformułowania wzbogacają naszą wrażliwość, rozszerzają horyzonty i czynią nas coraz lepszymi odbiorcami kultury.

\section{Bibliografia}

Burnett Mark Thornton, Lehmann Courtney, Rippy H. Marguerite, Ramona Wray, 2013, Welles, Kurosawa, Kozintsev, Zeffirelli. Great Shakespeareans. Volume XVII, London, Bloomsbury.

Gibińska Marta, Tabakowska Elżbieta, Duch ojca Hamleta a duch tekstu, 1993, w : Od Shakespeare'a do Szekspira, Ciechowicz J., Majchrowski Z. (red.), Gdańsk, s. 57-72.

Katafiasz Olga, 2005, Próby wrażliwości. Szekspirowskie ekranizacje Laurence'a Oliviera i Kennetha Branagha, Kraków.

Komedia Obyczajowa Warszawska, 1960, Wołoszyńska Z. (oprac. i wstęp), Warszawa.

\section{Filmografia}

Hamlet, reż. Laurence Olivier, Alan Dent, 1948

Zły śpi spokojnie, reż. Akira Kurosawa, 1960

Hamlet, reż. John Gielgud, Bill Colleran, 1964

Hamlet, reż. Grigori Kozincew, 1964

Hamlet, reż. Franco Zeffirelli, 1990

\section{Zdjęcia pochodzą z serwisów:}

Internet Movie Database http://www.imdb.com/title/tt0054460/mediaviewer/ rm2550051584; http://www.imdb.com/title/tt0058126/mediaviewer/ rm201964544

You Tube https://www.youtube.com/watch?v=Y4Nq7sFE3VY; https://www. youtube.com/watch? $v=v Z Q 5 r y S-Y v M$

The Nitrate Diva https://nitratediva.wordpress.com/tag/laurence-olivier/

\section{O Autorce:}

Agnieszka Kwiatkowska - profesorka w Zakładzie Literatury XX wieku, Teorii Literatury i Sztuki Przekładu UAM; bada poezję dwudziestego wieku, zwłaszcza twórczość Juliana Przybosia, pisarstwo kobiet i poezję dziecięcą. 
